\title{
Inositol 1,4,5-Trisphosphate-Gated Calcium Transport through Plasma Membranes in Nerve Terminals
}

\author{
Hiroshi Ueda, ${ }^{1}$ Shigeki Tamura, ${ }^{2}$ Nobuyuki Fukushima, ${ }^{1}$ Toshiaki Katada, ${ }^{3}$ Michio Ui, ${ }^{4}$ and Masamichi Satoh ${ }^{5}$ \\ ${ }^{1}$ Department of Pharmacology, Yokohama City University School of Medicine, Yokohama 236, 2Suntory Institute for \\ Biomedical Research, Osaka 618, ${ }^{3}$ Department of Physiological Chemistry, Faculty of Pharmaceutical Sciences, The \\ University of Tokyo, Tokyo 113, ${ }^{4}$ RIKEN, Wako 351-01, and ${ }^{5}$ Department of Molecular Pharmacology, Faculty of \\ Pharmaceutical Sciences, Kyoto University, Kyoto 606-01, Japan
}

We developed new biochemical approaches to demonstrate the presence of inositol 1,4,5-trisphosphate (InsP $\mathrm{P}_{3}$ )-gated calcium channels in presynaptic plasma membranes (SPM) and their involvement in the presynaptic receptor-mediated $\mathrm{Ca}^{2+}$ influx into nerve terminals. In perfusion experiments using SPM vesicles preloaded with ${ }^{45} \mathrm{Ca}^{2+}, \operatorname{Ins} \mathrm{P}_{3}$ elicited the release of ${ }^{45} \mathrm{Ca}^{2+}$ into perfusates in a saturable manner. The Ins $\mathrm{P}_{3}$ evoked ${ }^{45} \mathrm{Ca}^{2+}$ release from resealed SPM vesicles was more potent than that from resealed vesicles using any other subcellular fractions. Here we also report the involvement of Ins: $\mathrm{P}_{3}$ gated mechanisms in the presynaptic receptor-mediated $\mathrm{Ca}^{2+}$ influx into synaptosomes (nerve terminals) by use of such resealed vesicles reconstituted with purified $G_{i 1}$.

Key words: Ins $P_{3}$ receptor; presynaptic receptor; $G_{i 1}$; reconstitution; resealed vesicles; $\mathrm{Ca}^{2+}$
A wide variety of stimulation of receptors by hormones and neurotransmitters results in increased phosphoinositide turnover and mobilization of $\mathrm{Ca}^{2+}$ from intracellular stores (Berridge, 1993; Berridge and Irvine, 1984). Such post-receptor mechanisms involve the stimulation (or inhibition) (see Misawa et al., 1995) of phospholipase C (PLC)-mediated hydrolysis of phosphatidylinositol 4,5-bisphosphate giving rise to diacylglycerol and inositol 1,4,5-trisphosphate $\left(\operatorname{InsP} P_{3}\right)$. It is well known that $\operatorname{InsP}_{3}$ mobilizes $\mathrm{Ca}^{2+}$ from microsomal organelles, such as rough (Henne et al., 1987) and smooth endoplasmic reticulum (Payne and Fein, 1987) and calciosome (Volpe et al., 1988) in various secretory cells. Thus, it is likely that InsP $_{3}$-induced calcium mobilization from intracellular organelles is involved in hormone secretion with receptor stimulation.

On the other hand, it is also considered that neurotransmitter release occurs predominantly in nerve terminals in a calciumdependent manner. Although PLC is reported to be present in nerve terminals (Gerfen et al., 1988) and is assumed to play an important role in presynaptic receptor-mediated regulation of neurotransmitter release, details on the $\mathrm{InsP}_{3}$-mediated calcium mobilization in nerve terminals remain to be determined.

We have reported that kyotorphin (tyrosine-arginine), a neuropeptide that is characterized as a releaser of met-enkephalin from brain slices (Takagi et al., 1979), increased intracellular concentrations of $\mathrm{Ca}^{2+}$, measured by Quin-II fluorometry, and stimulated the uptake of ${ }^{45} \mathrm{Ca}^{2+}$ extracellularly added into brain synaptosomes (Ueda et al., 1986). However, because this ${ }^{45} \mathrm{Ca}^{2+}$ uptake was not

Received Sept. 26, 1995; revised Feb. 5, 1996; accepted Feb. 7, 1996.

Parts of this study were supported by Grants-in-Aid from the Ministry of Education, Science, and Culture of Japan, and grants from Kato Memorial Research Foundation and Pharmaceutical Research Foundation. The present study has been performed in the Department of Pharmacology, Faculty of Pharmaceutical Sciences, Kyoto University.

Correspondence should be addressed to Hiroshi Ueda, Department of Pharmacology, Faculty of Pharmaceutical Sciences, Nagasaki University, 1-14, Bunkyo-cho, Nagasaki 852, Japan.

Copyright $(1996$ Society for Neuroscience $\quad 0270-6474 / 96 / 162891-10 \$ 05.00 / 0$ affected by calcium channel blockers and kyotorphin had no effect on the membrane potential in synaptosomes (Ueda et al., 1986), it is unlikely that the voltage-dependent calcium channel is involved in this presynaptic mechanism. Most recently we have reported that kyotorphin stimulated PLC in synaptosomal membranes via $G_{i 1}$ by reconstitution experiments (Ueda et al., 1989). These findings suggest that kyotorphin elicits calcium entry into synaptosomes via an action of Ins $_{3}$ at the plasma membranes rather than by means of calcium mobilization from intrasynaptosomal organelles. Taking into account the reports that $\mathrm{InsP}_{3}$-specific binding sites are also found in plasma membranes of hepatocytes (Guillemette et al., 1988), lymphocytes (Khan et al., 1992), and neurons (Worley et al., 1987) and that $\mathrm{Ins}_{3}$ receptors are found immunohistochemically in plasma membranes of olfactory cilia (Cunningham et al., 1993) and in nerve terminals of deep cerebellar nuclei (Sharp et al., 1992), we speculated that $\mathrm{InsP}_{3}$-gated calcium channels other than voltage-operated ones are involved in the receptor-operated calcium transport through plasma membranes in nerve terminals. Indeed, there are reports that $\mathrm{InsP}_{3}$-gated calcium channels function in plasma membranes of human lymphocytes, mast cells, and liver (Kuno and Gardner, 1987; Guillemette et al., 1988; Penner et al., 1988). Here we attempted to obtain biochemical evidence for the presynaptic InsP $_{3}$-gated calcium channels in nerve terminals and clarify the molecular basis of mechanisms in kyotorphin receptor-mediated calcium incorporation into synaptosomes through experiments using resealed presynaptic plasma membrane (SPM) vesicles.

\section{MATERIALS AND METHODS}

Materials. InsP $\mathrm{P}_{3}$, inositol 1,3,4,5-tetrakisphosphate $\left(\mathrm{InsP}_{4}\right)$, inositol 1,4bisphosphate (Ins $\mathrm{P}_{2}$ ), inositol 4-monophosphate (InsP), and inositol (Ins) were purchased from Sigma (St. Louis, MO), and ${ }^{45} \mathrm{CaCl}_{2}$ was purchased from DuPont NEN (Boston, MA). Kyotorphin was a gift from Dr. M. Kubota (Daiichi Pharmaceuticals, Tokyo, Japan) or purchased from Sigma. Other reagents were of analytical grade and were purchased from Sigma or Wako Pure Chemicals (Osaka, Japan).

Preparation of subcellular fractions. Male Sprague-Dawley rats weighing $200-250 \mathrm{gm}$ were decapitated and the whole brains were homogenized in $10 \mathrm{vol}$ of $0.32 \mathrm{M}$ sucrose. The homogenates were centrifuged at 
$1000 \times g$ for $10 \mathrm{~min}$, and the supernatant was further centrifuged at $12,000 \times g$ for $20 \mathrm{~min}$. Resulting pellets were used for preparation of myelin, synaptosomes, and mitochondria, and the supernatant was used for preparation of microsomes by further centrifugation at $100,000 \times g$ for $60 \mathrm{~min}$, according to Gray and Whittaker (1962). Further subsynaptosomal fractions were prepared by discontinuous density gradient centrifugation of lysed synaptosomes, composed of $0.1,0.6,0.8,1.0$, and 1.2 M sucrose (Whittaker et al., 1964). Synaptic vesicles were obtained from the interface between 0.4 and $0.6 \mathrm{M}$ sucrose, SPM from that between 0.6 and $0.8 \mathrm{M}$ and between 0.8 and $1.0 \mathrm{M}$ sucrose, and presynaptic mitochondria from the pellet. $\left[\mathrm{Na}^{+} / \mathrm{K}^{+}\right]$ATPase and NADPH cytochrome c reductase activities in each subfraction were measured according to Verity (1972) and Kasper (1971), respectively.

Incorporation of ${ }^{45} \mathrm{Ca}^{2+}$ into and ${ }^{45} \mathrm{Ca}^{2+}$ release from subcellular preparations. For preparation of resealed vesicles, each subcellular preparation per rat brain was hypo-osmotically lysed with $10 \mathrm{ml}$ of $5 \mathrm{mM}$ Tris- $\mathrm{HCl}$ buffer, pH 7.5, containing $1 \mathrm{mM} \mathrm{MgCl}_{2}, 0.574 \mathrm{mM} \mathrm{CaCl}_{2}$, and $1 \mathrm{mM}$ ethylene glycol bis ( $\beta$-aminoethylether) $N, N, N^{\prime} N^{\prime}$-tetraacetic acid/EGT $\Lambda$ (TMC buffer) by a Potter-Elvehjem homogenizer and centrifuged at $10,000 \times g$ for $5 \mathrm{~min}$. The free $\left[\mathrm{Ca}^{2+}\right]$ in the TMC buffer was calculated to be $0.1 \mu \mathrm{M}$ (Fabiato and Fabiato, 1979). The obtained pellets were resuspended in TMC buffer. Aliquots (10 $\mathrm{mg}$ of protein) were incubated in $10 \mathrm{ml}$ of TMC buffer with ${ }^{45} \mathrm{Ca}^{2+}(0.5 \mu \mathrm{Ci})$ at $37^{\circ} \mathrm{C}$. At various periods of incubation $(0.5-35 \mathrm{~min})$, an aliquot $(100 \mu \mathrm{l})$ was removed and passed through a GF/C filter (Whatman, Maidstone, UK), followed by three washes with $3 \mathrm{ml}$ of TMC buffer. For preparation of "previously resealed vesicles," the incubation with ${ }^{45} \mathrm{Ca}^{2+}$ was preceded by prior incubation at $37^{\circ} \mathrm{C}$ for $30 \mathrm{~min}$ in its absence. In some experiments, to examine the ATPand calmodulin-dependent ${ }^{45} \mathrm{Ca}^{2+}$ incorporation, the free $\left[\mathrm{Ca}^{2+}\right]$ was adjusted to $10 \mu \mathrm{M}$, a concentration required for activation of $\mathrm{Ca}^{2}$ activated ATPase (calcium pump) by calmodulin using $0.109 \mathrm{mM} \mathrm{CaCl}$ and $0.1 \mathrm{~mm}$ EGTA. Furthermore, in such experiments using unlysed microsomes, the preparation was preloaded with ${ }^{45} \mathrm{Ca}^{2+}$ in the isoosmotic buffer containing (in $\mathrm{mM}$ ) $\mathrm{KCl} 145, \mathrm{NaCl} 5, \mathrm{MgCl}_{2} 1, \mathrm{CaCl}_{2} 0.574$,

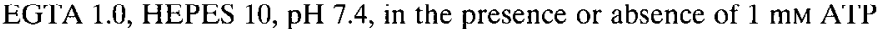
under the condition of $37^{\circ} \mathrm{C}$ for $30 \mathrm{~min}$. In the experiments for ${ }^{45} \mathrm{Ca}^{2+}$ incorporation into unlysed synaptosomes or saponin-treated permeabilized synaptosomes, another iso-osmotic buffer containing (in $\mathrm{mM}$ ) $\mathrm{NaCl}$ $145, \mathrm{KCl} 5, \mathrm{MgCl}_{2} 1, \mathrm{CaCl}_{2} 0.574$, EGTA 1.0 , HEPES $10, \mathrm{pH} 7.4$, in the presence or absence of $1 \mathrm{~mm}$ ATP was used. In the latter experiments, saponin $(30 \mu \mathrm{g} / \mathrm{ml})$ was added to the synaptosomes just before ${ }^{45} \mathrm{Ca}^{2+}$ incorporation. The accumulation of ${ }^{45} \mathrm{Ca}^{2+}$ was determined by measuring radioactivity on the filtcr.

The experiments of ${ }^{45} \mathrm{Ca}^{2+}$ release were performed essentially as described (Ueda et al., 1987). Briefly, aliquots $(300-500 \mu \mathrm{g}$ protein) of lysed preparations were incubated with ${ }^{45} \mathrm{CaCl}_{2}(0.5 \mu \mathrm{Ci})$ at $37^{\circ} \mathrm{C}$ for 30 min and centrifuged at $5000 \times g$ for $10 \mathrm{~min}$. The pellets were resuspended in a small volume of TMC buffer, loaded on GF/C filters (diameter 6 $\mathrm{mm}$ ), fixed in the chamber, and superfused in TMC buffer at a flow rate of $1 \mathrm{ml} / \mathrm{min}$. The ${ }^{45} \mathrm{Ca}^{2+}$ release from resealed vesicles was determined as "fractional release (\%)" by measurement of the ratio of the ${ }^{45} \mathrm{Ca}^{2+}$ release $(\mathrm{cpm})$ to the total ${ }^{45} \mathrm{Ca}^{2+}(\mathrm{cpm})$ in the preparation at the real time, as reported previously (Ueda et al., 1987). The total ${ }^{45} \mathrm{Ca}^{2+}$ was calculated by summation of ${ }^{45} \mathrm{Ca}^{2+}$ released into perfusates and remained in the preparation after the perfusion experiment. Other details in collection of perfusates, addition of drugs, and estimation of evoked release were also as described (Ueda et al., 1987).

Reconstitution of pertussis toxin-treated membranes with purified $G_{i l}$. The pretreatment of SPM with preactivated pertussis toxin (PTX) and reconstitution of PTX-treated membranes with purified $G_{i 1}$ or $G_{0}$ was performed as reported previously (Ueda et al., 1989). Briefly, freshly prepared SPM (2 mg protein) was pretreated with preactivated $50 \mu \mathrm{g} / \mathrm{ml}$ of PTX in a volume of $100 \mu \mathrm{l}$, followed by addition with purified $\mathrm{G}_{\mathrm{il}}$ or $\mathrm{G}_{\mathrm{o}}$ (20 pmol/assay).

${ }^{45} \mathrm{Ca}^{2+}$ influx into intact synaptosomes in membranes prepared from various regions of the rat brain. Procedures of ${ }^{45} \mathrm{Ca}^{2+}$ influx into synaptosomes from various brain regions have been reported previously (Ueda et al., 1986). Briefly, synaptosomes from various brain regions of the rat. were prepared as described by Whittaker (1964). After the brain synaptosomes had been preincubated in HEPES-buffered medium (HBM) at $37^{\circ} \mathrm{C}$ for $10 \mathrm{~min}, 100 \mu \mathrm{M}$ kyotorphin and ${ }^{45} \mathrm{CaCl}_{2}(0.1 \mu \mathrm{Ci})$ were added, the incubation extended for another $5 \mathrm{~min}$, then terminated by adding 5 $\mathrm{ml}$ of cold HBM, incubating $5 \mathrm{mM}$ EGTA instead of $\mathrm{CaCl}_{2}$. The preparation was then passed through a GF/C glass fiber filter (Whatman). This filter was washed three times with $\mathrm{Ca}^{2+}$-free HMB-EGTA (5 mM), and the radioactivity was counted. Kyotorphin-evoked ${ }^{45} \mathrm{Ca}^{2+}$ influx was represented as percentage of control without kyotorphin.

\section{RESULTS}

\section{Accumulation of ${ }^{45} \mathrm{Ca}^{2+}$ into resealed vesicles derived from SPM}

The first step in experiments of ${ }^{45} \mathrm{Ca}^{2+}$ accumulation into resealed vesicles was to incubate the freshly prepared (lysed) SPM with ${ }^{45} \mathrm{Ca}^{2+}$ in TMC buffer at $37^{\circ} \mathrm{C}$. Aliquots were periodically removed and passed through $\mathrm{GF} / \mathrm{C}$ filters to measure ${ }^{45} \mathrm{Ca}^{2+}$ accumulation. As shown in Figure $1 A,{ }^{45} \mathrm{Ca}^{2+}$ accumulation increased as the incubation time increased. There was a rapid increase in ${ }^{45} \mathrm{Ca}^{2+}$ accumulation within $1 \mathrm{~min}$, then a slow but linear increase within $20 \mathrm{~min}$. The ${ }^{45} \mathrm{Ca}^{2+}$ accumulation reached a plateau at 20-30 min. When $5 \mu \mathrm{M} \mathrm{A-23187,} \mathrm{a} \mathrm{calcium} \mathrm{ionophore,} \mathrm{was} \mathrm{added}$ to the incubation medium at $10 \mathrm{~min}$ after the beginning of incubation, the level of ${ }^{45} \mathrm{Ca}^{2+}$ accumulation decreased with further incubation (Fig. 1A). The ${ }^{45} \mathrm{Ca}^{2+}$ level at $15-30$ min after the start of the incubation was $6000 \mathrm{cpm} / \mathrm{mg}$ of protein in the presence of $5 \mu \mathrm{M} \mathrm{A}-23187$, and it was $55-57 \%$ of vehicle control without A-23187 at 20-30 min. Because the ${ }^{45} \mathrm{Ca}^{2+}$ level was the same with a higher concentration $(10 \mu \mathrm{M})$ of A-23187 (data not shown) it is likely that such a decrease by $43-45 \%$ is attributed to the incorporation of ${ }^{45} \mathrm{Ca}^{21}$ inside during formation of resealed SPM vesicles.

In another set of experiments, the SPM was preincubated in the absence of ${ }^{45} \mathrm{Ca}^{2+}$ at $37^{\circ} \mathrm{C}$ for $30 \mathrm{~min}$, followed by further incubation with ${ }^{45} \mathrm{Ca}^{2+}$ under the same condition, as mentioned above. In such preparations, the ${ }^{45} \mathrm{Ca}^{2+}$ accumulation was markedly reduced, compared with the previous set of experiments. The ${ }^{45} \mathrm{Ca}^{2+}$ accumulation reached a plateau at the level of $5000-5900$ $\mathrm{cpm} / \mathrm{mg}$ of protein at 10-30 min after the start of incubation with ${ }^{45} \mathrm{Ca}^{3+}$. Such a plateau level was as much as that observed in the previous set of experiments using A-23187. In addition, when 5 $\mu \mathrm{M} \mathrm{A}-23187$ was added to incubation medium at $10 \mathrm{~min}$, there was no more decrease in the level of ${ }^{45} \mathrm{Ca}^{2+}$ accumulation. Thus, it is suggested that ${ }^{45} \mathrm{Ca}^{2+}$ was not actively incorporated into previously resealed vesicles, but just bound to SPM vesicles or aggregates. The formation of resealed vesicles (mostly unilamellar type) during the incubation of lysed SPM was confirmed in electron microscope studies with a negative staining method (Fig. 1B).

\section{Characterization of ATP-dependent ${ }^{45} \mathrm{Ca}^{2+}$ incorporation into previously resealed SPM vesicles}

When the previously resealed vesicles were incubated with ${ }^{45} \mathrm{Ca}^{2+}$ in the presence of $1 \mathrm{mM}$ ATP, there was an active incorporation of ${ }^{45} \mathrm{Ca}^{2+}$ (Fig. $1 C$ ). Further addition of calmodulin at $5 \mu \mathrm{g} / \mathrm{ml}$ showed a marked potentiation of ATP-induced ${ }^{45} \mathrm{Ca}^{2+}$ incorporation, whereas calmodulin alone had no significant effect (Fig. 1C).

To characterize the SPM vesicles, the effect of saponin on ATP-dependent incorporation was studied. Saponin is known to form micelles with cholesterol mainly found in plasma membranes, and to form small pores in such membranes (Inamitsu and Ohtsuki, 1984). In such experiments, previously resealed SPM vesicles were incubated at $37^{\circ} \mathrm{C}$ for $30 \mathrm{~min}$ with free $\left[\mathrm{Ca}^{2+}\right]$ at 100 nM containing ${ }^{45} \mathrm{Ca}^{2+}$ in the presence or absence of $1 \mathrm{mM}$ ATP. The ATP-dependent ${ }^{45} \mathrm{Ca}^{2+}$ incorporation (mean $\pm \mathrm{SEM}$ ) defined to be the difference between ${ }^{45} \mathrm{Ca}^{2+}$ incorporations in the presence and absence of ATP was $699 \pm 20 \mathrm{cpm} /$ fraction $(0.25 \mathrm{mg}$ of protein) from three separate experiments. When various concentrations of saponin were added to resealed vesicles at $37^{\circ} \mathrm{C}$ for 

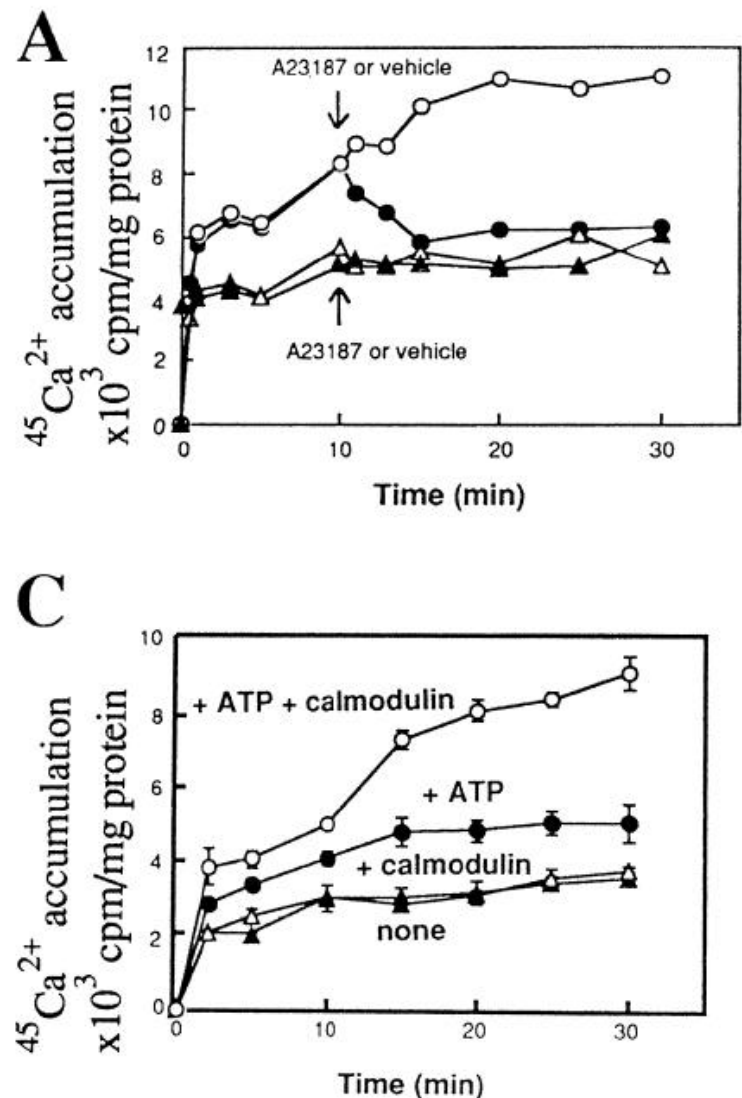

B
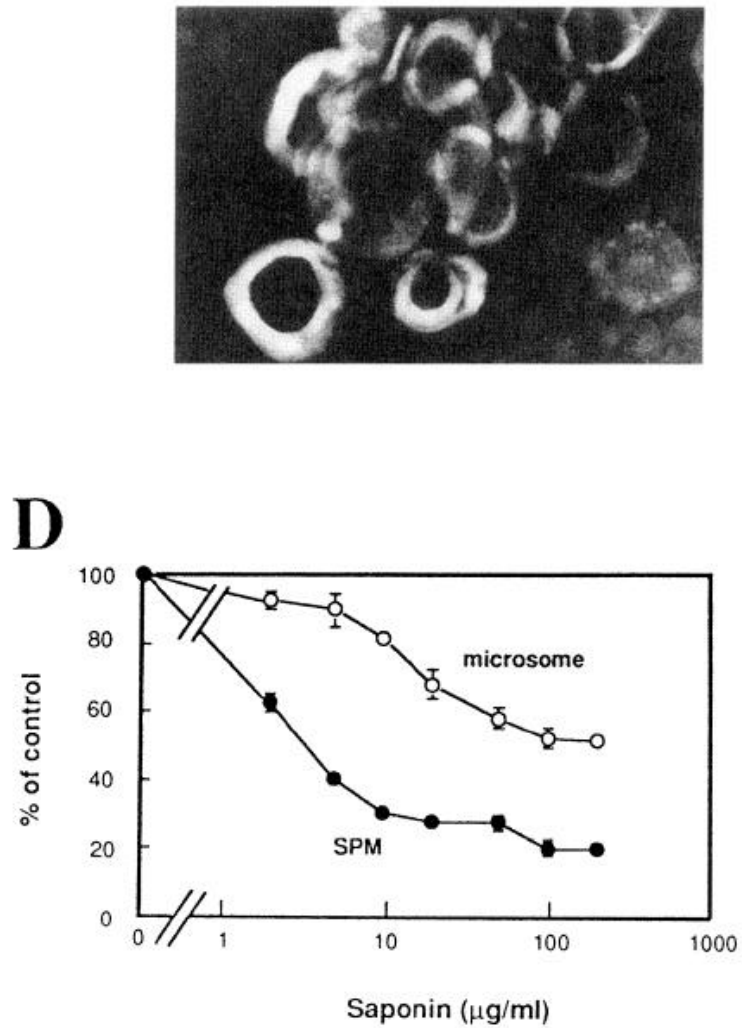

Figure 1. Accumulation of ${ }^{45} \mathrm{Ca}^{2+}$ into resealed vesicles derived from SPM. A, Freshly prepared SPM $(O, \bullet)$ or previously resealed SPM vesicles $(\triangle, \boldsymbol{\Delta})$ was incubated with ${ }^{45} \mathrm{Ca}^{2+}$, and aliquot $(100 \mu \mathrm{l})$ at each incubation time was used for determination of ${ }^{45} \mathrm{Ca}^{2+}$ incorporation, as described in Experimental Procedures. Results in the figure are representative profiles of the time course of ${ }^{45} \mathrm{Ca}^{2+}$ accumulation. Vehicle $(\mathrm{O}, \triangle)$ or $5 \mu \mathrm{M} A-23187(\boldsymbol{\bullet}, \boldsymbol{\Delta})$ was added to the assay tube at $10 \mathrm{~min}$. $B$, An electron microscopic (negative-staining) image of the resealed SPM vesicles. $C$, Time course of ATP- and calmodulin-dependent ${ }^{45} \mathrm{Ca}^{2+}$ accumulation into previously resealed SPM vesicles, which was prepared in Experimental Procedures. Vehicle $(\boldsymbol{\Delta}), 5 \mu \mathrm{g} / \mathrm{ml}$ of calmodulin $(\triangle), 1 \mathrm{~mm} \mathrm{ATP}(\bullet)$, or $5 \mu \mathrm{g} / \mathrm{ml}$ calmodulin plus $1 \mathrm{~mm}$ ATP $(O)$ was added simultaneously with ${ }^{45} \mathrm{Ca}^{2+}$ to the tube containing previously resealed SPM vesicles. Experiments were performed under the condition of free $\left[\mathrm{Ca}^{2+}\right]$ at $10 \mu \mathrm{M}$ using $0.109 \mathrm{mM} \mathrm{CaCl}$ and $0.1 \mathrm{mM}$ EGTA. Each point of data represents the mean \pm SEM from three separate experiments. $D$, Blockade of ${ }^{45} \mathrm{Ca}^{2+}$ accumulation into resealed SPM vesicles and unlysed microsomes by pretreatment with various concentrations of saponin. In both experiments using resealed SPM vesicles and unlysed microsomes, incubation was carried out at $37^{\circ} \mathrm{C}$ for 30 min under the condition of free $\left[\mathrm{Ca}^{2+}\right]$ at $100 \mathrm{nM}$ in the presence or absence of $1 \mathrm{mM}$ ATP. In resealed SPM vesicles, the ATP-dependent ${ }^{45} \mathrm{Ca}^{2+}$ incorporation in control (without saponin) resealed SPM vesicles $(0.25 \mathrm{mg}$ of protein/fraction) was $699 \pm 20 \mathrm{cpm} / \mathrm{fraction}$. Experiments using intact microsomes were performed as described in Experimental Procedures. The ATP-dependent ${ }^{45} \mathrm{Ca}^{2+}$ incorporation in control microsomes $(0.25 \mathrm{mg}$ of protein/fraction) was $209 \pm 9.3 \mathrm{cpm} /$ fraction. Data represent the mean \pm SEM from three separate experiments.

5 min before incorporation of ${ }^{45} \mathrm{Ca}^{2+}$ in the presence of ATP, the ATP-dependent incorporation of ${ }^{45} \mathrm{Ca}^{2+}$ was inhibited by saponin in a concentration-dependent manner (Fig. $1 D$ ). The $\mathrm{IC}_{50}$ of saponin was $3.5 \mu \mathrm{g} / \mathrm{ml}$. On the other hand, the ATP-dependent incorporation of ${ }^{45} \mathrm{Ca}^{2+}$ into unlysed microsomes was $2090 \pm 93$ $\mathrm{cpm} /$ fraction $(0.25 \mathrm{mg}$ of protein) from three separate experiments. As shown in Figure $1 D$, however, the ATP-dependent ${ }^{45} \mathrm{Ca}^{2+}$ incorporation into microsomes was less sensitive to saponin treatment than that into SPM vesicles. The $\mathrm{IC}_{50}$ of saponin in microsomal preparations was $>100 \mu \mathrm{g} / \mathrm{ml}$.

\section{InsP $\mathrm{P}_{3}$-evoked ${ }^{45} \mathrm{Ca}^{2+}$ release from resealed SPM vesicles and effects of A-23187 pretreatment on it}

We examined the InsP $\mathrm{P}_{3}$-mediated ${ }^{45} \mathrm{Ca}^{2+}$ release from resealed SPM vesicles, prepared as follows: the freshly prepared SPM was incubated with ${ }^{45} \mathrm{Ca}^{2+}$ in TMC buffer at $37^{\circ} \mathrm{C}$ for $30 \mathrm{~min}$, placed on GF/C filters, and perfused in the TMC buffer. As shown in Figure $2 A$, the basal release of ${ }^{45} \mathrm{Ca}^{2+}$ rapidly decreased and reached a plateau 20 min after the onset of perfusion. The ${ }^{45} \mathrm{Ca}^{2+}$ release was increased by the addition to the medium of $\operatorname{InsP}_{3}$ at 5 $\mu \mathrm{M}$ at the 25 th and 26th minute, and resting levels were restored by its omission. A-23187, a calcium ionophore added at the 31st and 32 nd minute, showed a similar but greater increase in ${ }^{45} \mathrm{Ca}^{2+}$ release, even after treatment with $\mathrm{InsP}_{3}$. However, when A-23187 was pretreated at the 11th and 12th minute, there was no longer any increase in ${ }^{45} \mathrm{Ca}^{2+}$ release by following InsP $\mathrm{P}_{3}$ challenge (Fig. $2 B$ ). The addition of EGTA, a calcium chelating agent, caused a similar ${ }^{45} \mathrm{Ca}^{2+}$ release, and there was no effect on the ${ }^{45} \mathrm{Ca}^{2+}$ release by following InsP $_{3}$ and A-23187 challenges (Fig. 2C). These findings suggest that EGTA releases ${ }^{45} \mathrm{Ca}^{2+}$ into perfusates by taking off ${ }^{45} \mathrm{Ca}^{2+}$, which is adsorbed to vesicles, whereas both challenges with InsP $\mathrm{P}_{3}$ and A-23187 release ${ }^{45} \mathrm{Ca}^{2+}$ from the inside of vesicles.

\section{Characterization of Ins $\mathrm{P}_{3}$-mediated ${ }^{45} \mathrm{Ca}^{2+}$ release from resealed SPM vesicles}

To further characterize the $\mathrm{InsP}_{3}$-evoked ${ }^{45} \mathrm{Ca}^{2+}$ release, the concentration of ${ }^{45} \mathrm{Ca}^{2+}$ to be preloaded into newly resealed vesicles was varied. To normalize the variations among separate experiments, we evaluated the $\mathrm{InsP}_{3}$ (or related compounds)evoked ${ }^{45} \mathrm{Ca}^{2+}$ release as a fractional release, a ratio (\%) of the amount (cpm) of ${ }^{45} \mathrm{Ca}^{2+}$ in each fraction to the total amounts 

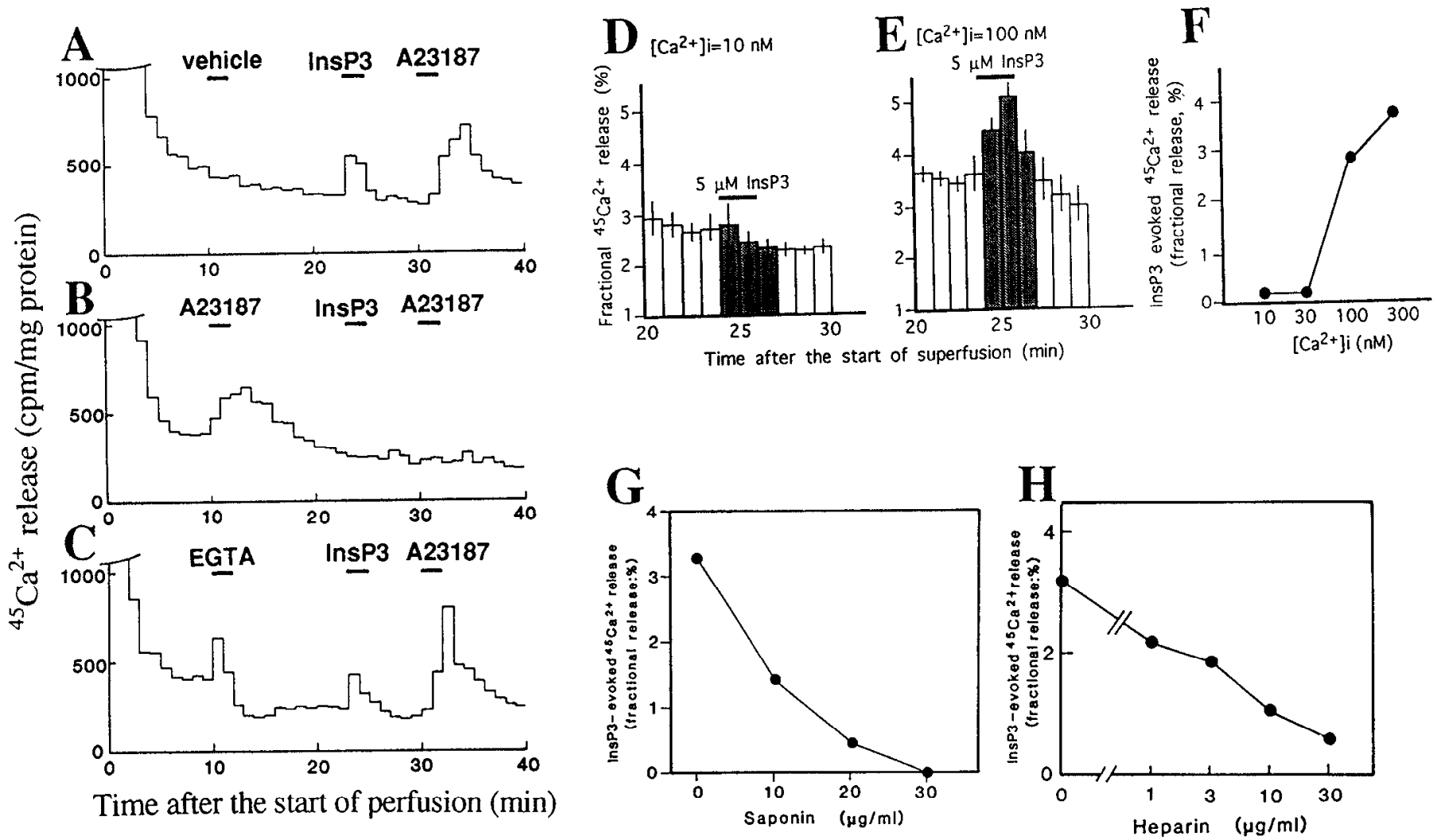

Figure 2. Characterization of InsP $\mathrm{P}_{3}$-evoked ${ }^{45} \mathrm{Ca}^{2+}$ release from resealed SPM vesicles. $A$, InsP $\mathrm{P}_{3}$ - or $\mathrm{A}-23187$-evoked ${ }^{45} \mathrm{Ca}^{2+}$ release. Data in the figure are representative results. Resealed SPM vesicles preloaded with ${ }^{45} \mathrm{Ca}^{2+}$ were perfused at a flow of $1 \mathrm{ml} / \mathrm{min}$ in TMC buffer. Each 1 min perfusate was collected for measurement of radioactivity. Results represent ${ }^{45} \mathrm{Ca}^{2+}(\mathrm{cpm})$ released/mg protein of SPM. Vehicle, InsP $3 \mathrm{P}_{3}(5 \mathrm{M})$, or A-23187 $(5 \mu \mathrm{M})$ was added to the perfusion medium at the indicated time. $B$, Blockade of $\operatorname{InsP}_{3}$-evoked ${ }^{45} \mathrm{Ca}^{2+}$ release by pretreatment with $A$-23187. $C$, Lack of effect on InsP $P_{3}$-evoked ${ }^{45} \mathrm{Ca}^{2+}$ release by pretreatment with EGTA. $D$, No significant InsP $\mathrm{P}_{3}$-evoked ${ }^{45} \mathrm{Ca}^{2+}$ release in the case with $10 \mathrm{nM}\left[{ }^{45} \mathrm{Ca}^{2+}\right]_{\mathrm{i}}(n=3)$. Results represent the fractional release $(\%)$ as described in Results. $E$, Ins $\mathrm{P}_{3}$-evoked ${ }^{45} \mathrm{Ca}^{2+}$ release (fractional rclease/\%) in the casc with $100 \mathrm{nM}\left[{ }^{45} \mathrm{Ca}^{2+}\right] \mathrm{i}$ $(n=3) . F,\left[{ }^{45} \mathrm{Ca}^{2+}\right]$ i dependency of InsP $\mathrm{P}_{3}$-evoked ${ }^{45} \mathrm{Ca}^{2+}$ release $(n=3)$. InsP $\mathrm{P}_{3}$-evoked ${ }^{45} \mathrm{Ca}^{2+}$ release was described in Results. $G$, Concentrationdependent inhibition of $\mathrm{InsP}_{3}$-evoked ${ }^{45} \mathrm{Ca}^{2+}$ release by saponin. $\mathrm{H}$, Concentration-dependent inhibition of InsP $\mathrm{P}_{3}$-evoked ${ }^{45} \mathrm{Ca}^{2+}$ release by heparin.

(cpm) at real time (Ueda et al., 1987). The basal ${ }^{45} \mathrm{Ca}^{2+}$ release $(\%)$ was represented as the sum of six fractional releases from the 22nd to the 24 th minute and from the 28 th to the 30 th minute/2, and the $\mathrm{Ins}_{3}$-evoked increase $(\%)$ in the ${ }^{45} \mathrm{Ca}^{2+}$ release was then represented as the sum of three fractional releases from the 25 th to the 27th minute-the basal ${ }^{45} \mathrm{Ca}^{2+}$ release. As shown in Figure $2 D$, there was no significant $\operatorname{InsP}_{3}(5 \mu \mathrm{M})$-evoked ${ }^{45} \mathrm{Ca}^{2+}$ release in the case with $\left[{ }^{45} \mathrm{Ca}^{2+}\right]_{\mathrm{i}}=10 \mathrm{nM}$. When the $\left[{ }^{45} \mathrm{Ca}^{2+}\right]_{\mathrm{i}}$ was increased to $100 \mathrm{~nm}$, an identical concentration to free $\left[\mathrm{Ca}^{2+}\right]_{0}$ in perfusion medium (TMC), there was a marked ${ }^{45} \mathrm{Ca}^{2+}$ release (Fig. 2E). As expected, the InsP $\mathrm{P}_{3}$-evoked ${ }^{45} \mathrm{Ca}^{2+}$ release was further increased at $\left.{ }^{45} \mathrm{Ca}^{2+}\right]_{\mathrm{i}}=300 \mathrm{nM}$ (Fig. $2 F$ ).

When resealed SPM vesicles were pretreated $\left(5 \mathrm{~min}\right.$ at $\left.37^{\circ} \mathrm{C}\right)$ with saponin, the $\mathrm{InsP}_{3}(5 \mu \mathrm{M})$-cvokcd ${ }^{45} \mathrm{Ca}^{2+}$ relcase was decreased (Fig. 2G). The $\mathrm{IC}_{50}$ of saponin for InsP $\mathrm{P}_{3}$-evoked ${ }^{45} \mathrm{Ca}^{2+}$ release was $9 \mu \mathrm{g} / \mathrm{ml}$, a value equivalent to data obtained with ${ }^{45} \mathrm{Ca}^{2+}$ incorporation, as mentioned above. On the other hand, when $1-30 \mu \mathrm{g} / \mathrm{ml}$ of heparin, known to be a putative InsP $_{3}$ antagonist (Worley et al., 1987; Ehrlich and Watras, 1988; Kobayashi et al., 1988), was added to the perfusion medium from the 10th minute to the end of perfusion, the $\mathrm{InsP}_{3}$-evoked ${ }^{45} \mathrm{Ca}^{2+}$ release was markedly inhibited (Fig. $2 H$ ). The $\mathrm{IC}_{50}$ of heparin was $4.8 \mu \mathrm{g} / \mathrm{ml}$, a value in good accord with its $\mathrm{IC}_{50}$ in $\mathrm{InsP}_{3}$ binding in cerebellar membranes (Worley et al., 1987).

\section{Kinetics of ${ }^{45} \mathrm{Ca}^{2+}$ release evoked by Ins $\mathrm{P}_{3}$ and related compounds from resealed SPM vesicles}

The InsP ${ }_{3}$-evoked increase in ${ }^{45} \mathrm{Ca}^{2+}$ release from resealed SPM vesicles was concentration-dependent in ranges of $0.5-10 \mu \mathrm{M}$ $\mathrm{InsP}_{3}$ and $\mathrm{InsP}_{4}$, and these effects appeared to be saturable (Fig. $3 A$ ). The double-reciprocal plot showed that apparent $K_{\mathrm{m}}$ and maximal response were $1.5 \mu \mathrm{M}$ and $4.16 \%$ for InsP $\mathrm{P}_{3}$, whereas they were $1.5 \mu \mathrm{M}$ and $2.54 \%$ for $\operatorname{InsP}_{4}$ (Fig. $3 B$ ). Ins, InsP, and InsP evoked less marked releases compared with $\mathrm{InsP}_{3}$ and $\mathrm{InsP}_{4}$. In addition, the concentration-response curves with InsP and InsP $P_{2}$ were bell-shaped, and thereby kinetic analyses could not be performed. On the other hand, Ins evoked a weak but concentrationdependent ${ }^{45} \mathrm{Ca}^{2+}$ release. It remains unclear whether this effect is attributed to the action on $\mathrm{InsP}_{3}, \mathrm{InsP}_{4}$, or other receptors. Details of these weak actions must be further characterized in subsequent studies.

\section{${ }^{45} \mathrm{Ca}^{2+}$ release evoked by InsP $\mathrm{P}_{3}$ from various resealed vesicles composed of different subcellular fractions}

To examine the subcellular specificity of $\mathrm{InsP}_{3}$-evoked ${ }^{45} \mathrm{Ca}^{2+}$ release, the effects of InsP $\mathrm{P}_{3}$ on the ${ }^{45} \mathrm{Ca}^{2+}$ release were studied in various subcellular preparations (Table 1). As expected, the highest $\mathrm{Na}^{+} / \mathrm{K}^{+}$ATPase activity (a marker enzyme for plasma membranes) was observed in the fractions of microsomes and myelins. A modest level of activity was detected in the synaptosomal 

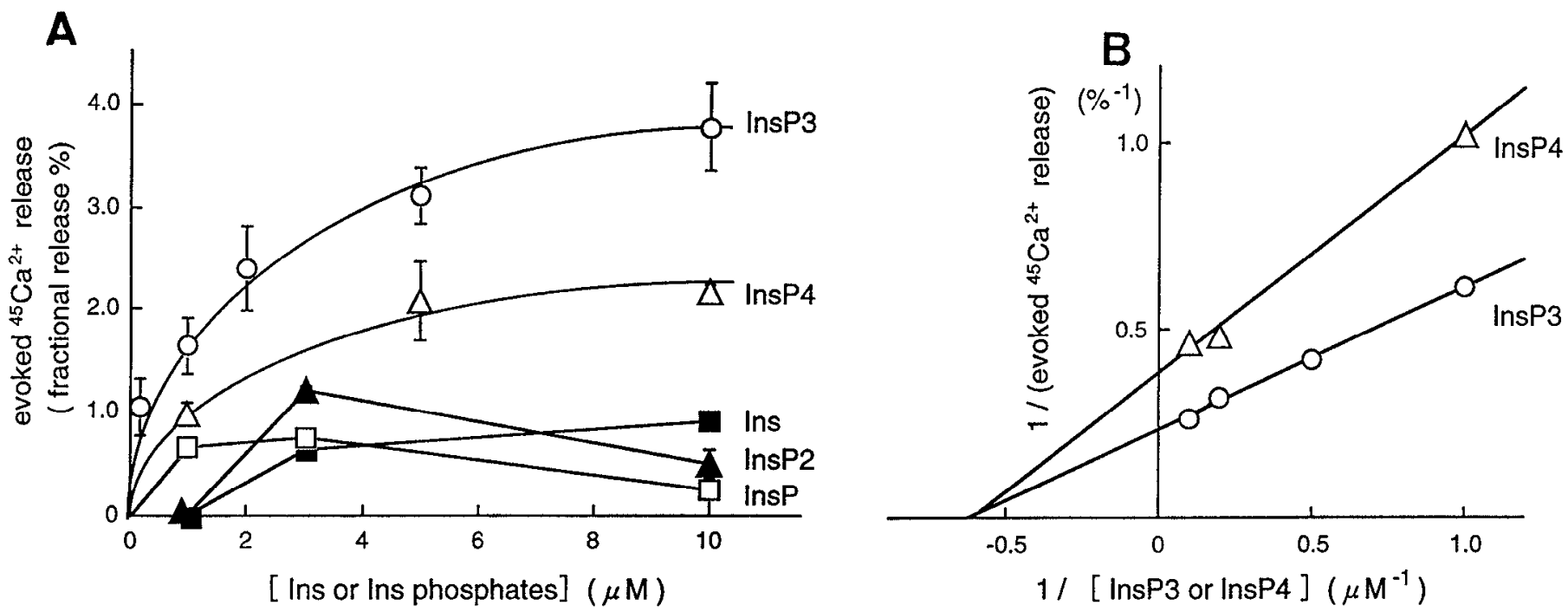

Figure 3. Kinetics of ${ }^{45} \mathrm{Ca}^{2+}$ release evoked by $\mathrm{InsP}_{3}$ and related compounds from resealed vesicles of lysed synaptosomes preloaded with ${ }^{45} \mathrm{Ca}{ }^{2+}$ $A$, Concentration-dependent curve of evoked ${ }^{45} \mathrm{Ca}^{2+}$ release (\% fractional release) by various concentrations of $\operatorname{Ins} \mathrm{P}_{3}(O), \operatorname{InsP}_{4}(\triangle), \operatorname{InsP}_{2}(\Delta), \operatorname{InsP}(\square)$, and inositol ( $\square$. Each experiment was performed in the same preparation so that the kinetics of test compounds can be compared. The data represent the mean \pm SEM from three separate experiments. $B$, Double-reciprocal plots of InsP $3^{-}$or InsP $4_{4}$-evoked ${ }^{45} \mathrm{Ca}^{2+}$ release.

fraction. When the synaptosomal fraction was further separated into synaptic vesicles, SPM, and presynaptic mitochondria, highest activity was found in the SPM.

On the other hand, NADPH cytochrome c reductase is known to be a marker enzyme for endoplasmic reticulum. This activity was highly found in the microsomal fraction and there was less marked activity in the synaptosomal fraction and its subfractions (Table 1). All subcellular fractions prepared here were hypoosmotically lysed in TMC and immediately preloaded with ${ }^{45} \mathrm{Ca}^{2+}$, as mentioned above in the case with SPM. As shown in Table 1 , the basal fractional ${ }^{45} \mathrm{Ca}^{2+}$ release after $\operatorname{InsP}_{3}$ challenges was similar among all these preparations. However, the $\mathrm{InsP}_{3^{-}}$ evoked ${ }^{45} \mathrm{Ca}^{2+}$ release was bigger in the resealed SPM vesicles than in the other resealed vesicles. In this experiment, we measured only total amounts of ${ }^{45} \mathrm{Ca}^{2+}$ uptake in each subcellular preparation for evaluating basal percentage release or $\operatorname{InsP}_{3^{-}}$ evoked percentage release, but such total amounts do not represent intravesicular ${ }^{45} \mathrm{Ca}^{2+}$ concentrations. Because the incorporation of ${ }^{45} \mathrm{Ca}^{2+}$ into such resealed vesicles is expected to have occurred in a passive manner, however, the fractional percentage release obtained in the present study should be closely related to this intravesicular concentration. Indeed, the basal percentage release was quite similar among these preparations (Table 1). Therefore, it is likely that the difference of $\mathrm{Ins}_{3}$-evoked release is not attributed to the variation of ${ }^{45} \mathrm{Ca}^{2+}$ uptake among these subfractional preparations, but to specific mechanisms for $\operatorname{InsP}_{3}$ localized in synaptosomes or SPM.

Here we studied the $\mathrm{InsP}_{3}$-evoked ${ }^{45} \mathrm{Ca}^{2+}$ release from intrasynaptosomal organelles. As shown in Figure $4 A$, neither AlPdependent nor A-23187-sensitive ${ }^{45} \mathrm{Ca}^{2+}$ accumulation was observed in unlysed synaptosomes. In such unlysed synaptosomes that had been incubated with ${ }^{45} \mathrm{Ca}^{2+}, 5 \mu \mathrm{M}$ InsP $P_{3}$ had no effect on ${ }^{45} \mathrm{Ca}^{2+}$ release (Fig. 4B). On the other hand, in saponin-permeabilized synaptosomes, there was a significant ATP-dependent and A-23187sensitive ${ }^{45} \mathrm{Ca}^{2+}$ accumulation (Fig. $4 C$ ), whereas $5 \mu \mathrm{M} \mathrm{InsP}_{3}$ had no significant effect on ${ }^{45} \mathrm{Ca}^{2+}$ release from the permeabilized synaptosomes loaded with ${ }^{45} \mathrm{Ca}^{2+}$ in the presence of ATP (Fig. $4 D$ ). These findings suggest that some intrasynaptosomal micro-organelles are

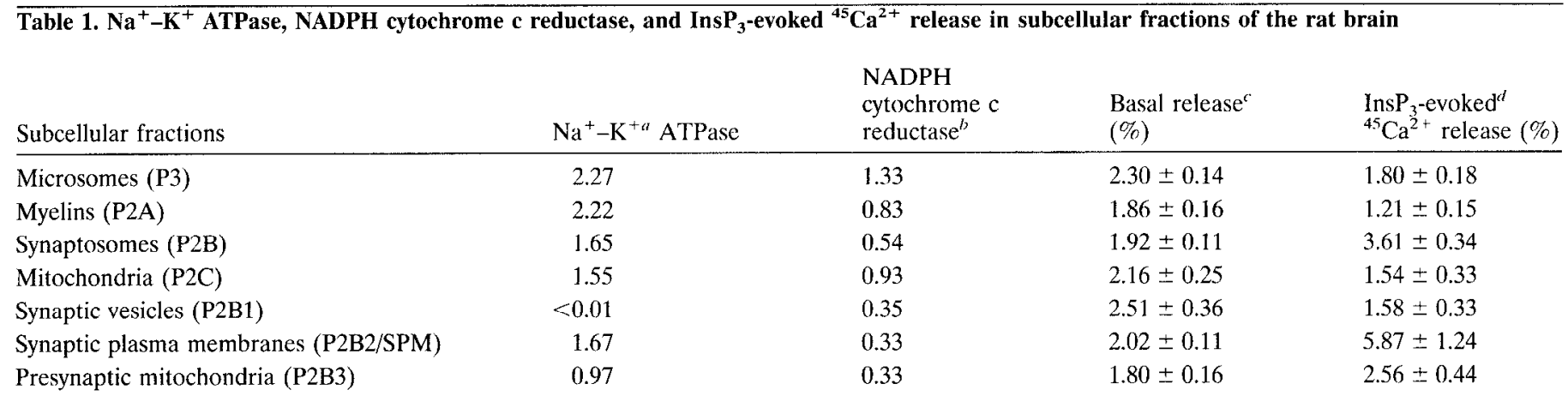

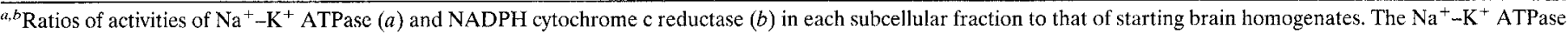
activity and NADPH-cytochrome $\mathrm{c}$ reductase in starting homogenates were $0.112 \mathrm{mmol} / \mathrm{mg}$ of protein/min and $5.98 \mathrm{nmol} / \mathrm{mg}$ of protein/min, respectively.

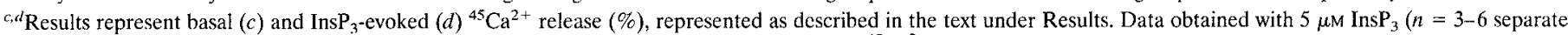
experiments) in various subcellular preparations $(300-500 \mu \mathrm{g} / \mathrm{assay})$ lysed and preloaded with ${ }^{45} \mathrm{Ca}^{2+}$.

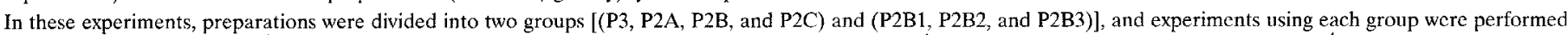

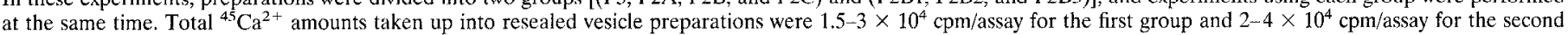
group. Marked variations were not observed among subfractions in each group.
} 


\section{Unlysed synaptosomes}
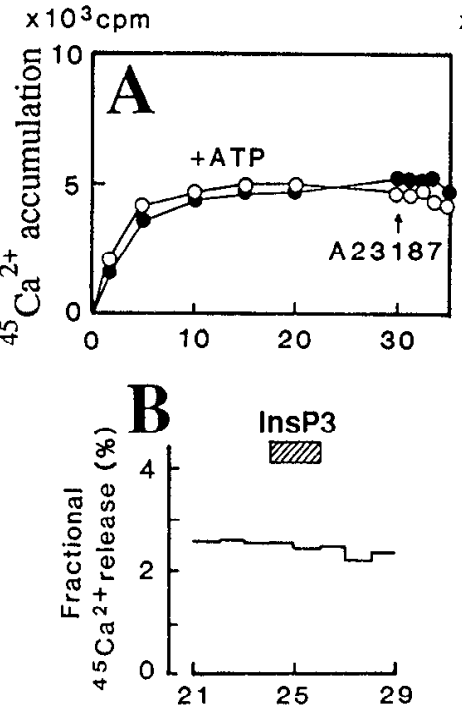

Permeabilized synaptosomes

\section{Unlysed non-synapto- somal microsomes}
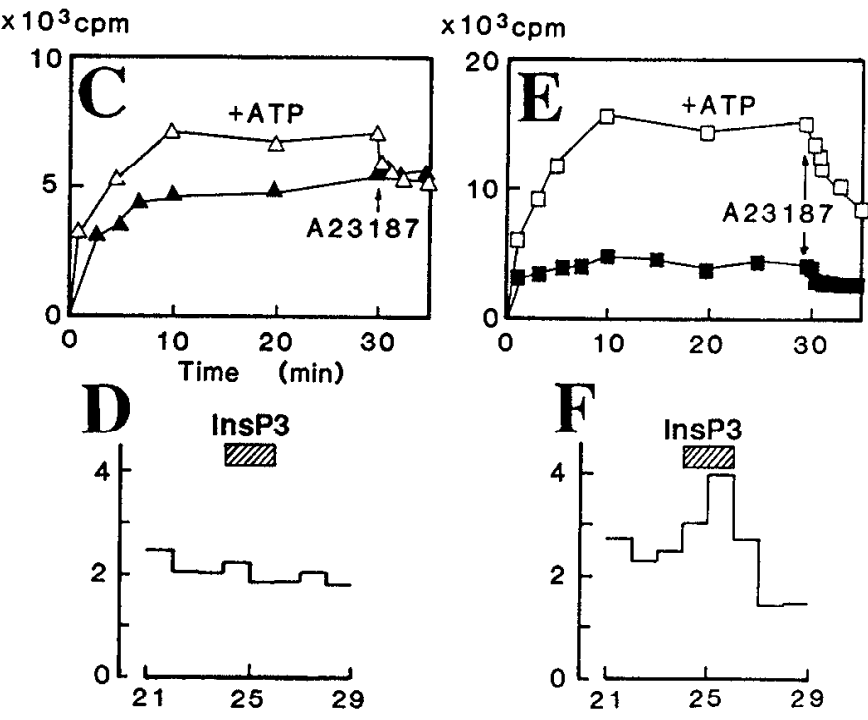

Time after the start of perfusion (min)

Figure 4. Lack of InsP $\mathrm{P}_{3}$-evoked ${ }^{45} \mathrm{Ca}^{2+}$ release from permeabilized synaptosomes. $A$, Lack of $\mathrm{A}$-23187-sensitive ${ }^{45} \mathrm{Ca}^{2+}$ incorporation into unlysed synaptosomes. $B$, Lack of $\mathrm{InsP}_{3}$-evoked ${ }^{45} \mathrm{Ca}^{2+}$ release from unlysed synaptosomes. $C$, ATP-dependent and A-23187-sensitive ${ }^{45} \mathrm{Ca}^{\text {?+ }}$ incorporation into saponin-permeabilized synaptosomes. $D$, Lack of InsP $\mathrm{P}_{3}$-evoked ${ }^{45} \mathrm{Ca}^{2+}$ release from saponin-permeabilized synaptosomes. $E$, Potent ATP-dependent and A-23187-sensitive ${ }^{45} \mathrm{Ca}^{2+}$ incorporation into microsomes. $F, \mathrm{InsP}_{3}$-evoked ${ }^{45} \mathrm{Ca}^{2+}$ release from microsomes. Other details are given in the legends of Figures 1 and 2.

storage sites for ${ }^{45} \mathrm{Ca}^{2+}$, but they are unlikely targets for $\mathrm{InsP}_{3^{-}}$ evoked calcium mobilization. As mentioned before, a marked ATPdependent and A-23187-sensitive ${ }^{45} \mathrm{Ca}^{2+}$ accumulation was observed in unlysed microsomes that had been prepared from nonsynaptosomal microsomes, as shown in Figure $4 E$. As expected, InsP $\mathrm{P}_{3}$ evoked a significant ${ }^{45} \mathrm{Ca}^{2+}$ release from such unlysed microsomes (Fig. $4 F$ ).

\section{Kyotorphin-evoked ${ }^{45} \mathrm{Ca}^{2+}$ release from resealed SPM vesicles and its guanine nucleotide dependency}

Here we studied the receptor-mediated ${ }^{45} \mathrm{Ca}^{2+}$ release from resealed SPM vesicles of the whole brain, as described above in the case with $\operatorname{Ins}_{3}$. Previously we have reported that kyotorphin evoked ${ }^{45} \mathrm{Ca}^{2+}$ release in such resealed vesicles using SPM, and it was antagonized by leucine-arginine (Ueda et al., 1987), a kyotorphin receptor antagonist (Ueda et al., 1989). In the present experiments, we added GppNHp (an unhydrolyzable analog of GTP) together with kyotorphin in this system to study the involvement of G-proteins in such a receptor-mediated ${ }^{45} \mathrm{Ca}^{2+}$ release in resealed SPM vesicles. Kyotorphin and GppNHp had potentiating effects to each other in evoking ${ }^{45} \mathrm{Ca}^{2+}$ release from such preparations in a concentration-dependent manner, as shown in Figure $5, A$ and $B$. The $K_{\mathrm{m}}$ value and maximal response by GppNHp alone were $3.0 \mu \mathrm{M}$ and $5.0 \%$, respectively. The addition of $100 \mu \mathrm{M}$ kyotorphin decreased the $K_{\mathrm{m}}$ value to $0.4 \mu \mathrm{M}$ and slightly increased the maximal response to $8.3 \%$. On the other hand, the $K_{\mathrm{m}}$ value and maximal response by kyotorphin alone was $2.5 \mu \mathrm{M}$ and $1.6 \%$, respectively. The addition of $10 \mu \mathrm{M}$ GppNHp resulted in no change in $K_{\mathrm{m}}$ value $(2.5 \mu \mathrm{M})$, but it did increase the maximal response to $7.8 \%$. The ${ }^{45} \mathrm{Ca}^{2+}$ release by $100 \mu \mathrm{M}$ kyotorphin plus $10 \mu \mathrm{M}$ GppNHp was completely blocked in the presence of 100 $\mu \mathrm{M}$ leucine-arginine (data not shown), as reported previously in experiments without GppNHp (Ueda et al., 1987). Thus, it is suggested that the kyotorphin receptor-mediated ${ }^{45} \mathrm{Ca}^{2+}$ release is possibly mediated through G-proteins.

\section{Blockade of kyotorphin-evoked ${ }^{45} \mathrm{Ca}^{2+}$ release by PTX treatment and by addition with neomycin}

To study the involvement of G-proteins in the kyotorphin-evoked ${ }^{45} \mathrm{Ca}^{2+}$ release, SPM was pretreated with preactivated PTX. In such treatments, we used highly densed SPM (20 mg protein/ml) so as not to form resealed vesicles before ${ }^{45} \mathrm{Ca}^{2+}$ incorporation. As shown in Figure 5, $C$ and $D$, a marked reduction of ${ }^{45} \mathrm{Ca}^{2+}$ release by $100 \mu \mathrm{M}$ kyotorphin plus $10 \mu \mathrm{M}$ GppNHp was observed at $30-50 \mu \mathrm{g} / \mathrm{ml}$ PTX, concentrations in good accordance with our previous experiments including PTX-catalyzed ADP ribosylation (Ueda et al., 1989).

On the other hand, the ${ }^{45} \mathrm{Ca}^{2+}$ release evoked by $100 \mu \mathrm{M}$ kyotorphin plus $10 \mu \mathrm{M}$ GppNHp or by $10 \mu \mathrm{M}$ GppNHp was concentration-dependently inhibited by $300 \mu \mathrm{M}$ neomycin, which was added to the perfusion medium from the beginning of experiments (Fig. 5E). The $\mathrm{IC}_{50}$ of neomycin was $30 \mu \mathrm{M}$ (Fig. 5F), a comparable concentration in inhibiting PLC activity (Cockcroft and Gomperts, 1985).

\section{Recovery of kyotorphin-evoked release of ${ }^{45} \mathrm{Ca}^{2+}$ from resealed SPM vesicles that had been treated with PTX by reconstitution with purified $G_{i 1}$ but not with $G_{0}$}

The PTX $(50 \mu \mathrm{g} / \mathrm{ml})$-treated SPM was reconstituted with $\mathrm{G}_{i 1}$ or $\mathrm{G}_{\mathrm{o}}$, which had been purified ( $>95 \%$ purity) from porcine brains (Katada et al., 1987) by incubation at $4^{\circ} \mathrm{C}$ for $60 \mathrm{~min}$ in the presence of $0.01 \%$ of CHAPS (a detergent), as described previously (Ueda et al., 1989). As shown in Figure 6, $A$ and $B$, the ${ }^{45} \mathrm{Ca}^{2}$ ' release evoked by $10 \mu \mathrm{M}$ kyotorphin and $100 \mu \mathrm{M}$ GppNHp, but not by $100 \mu \mathrm{M}$ GppNHp alone, was significantly 


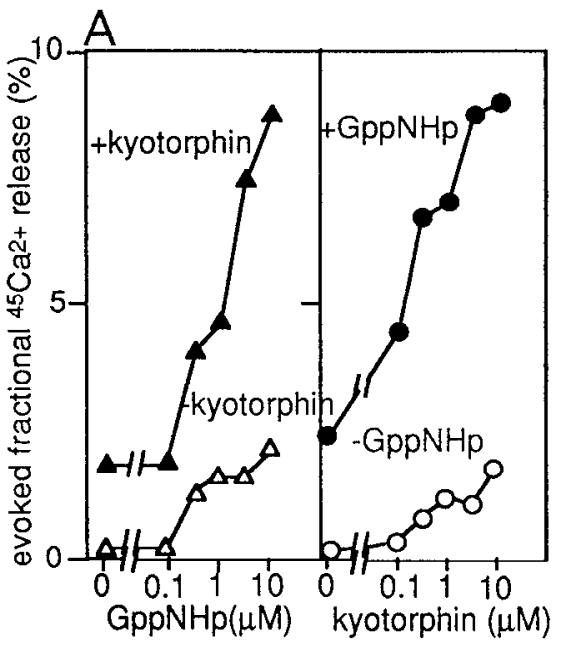

B
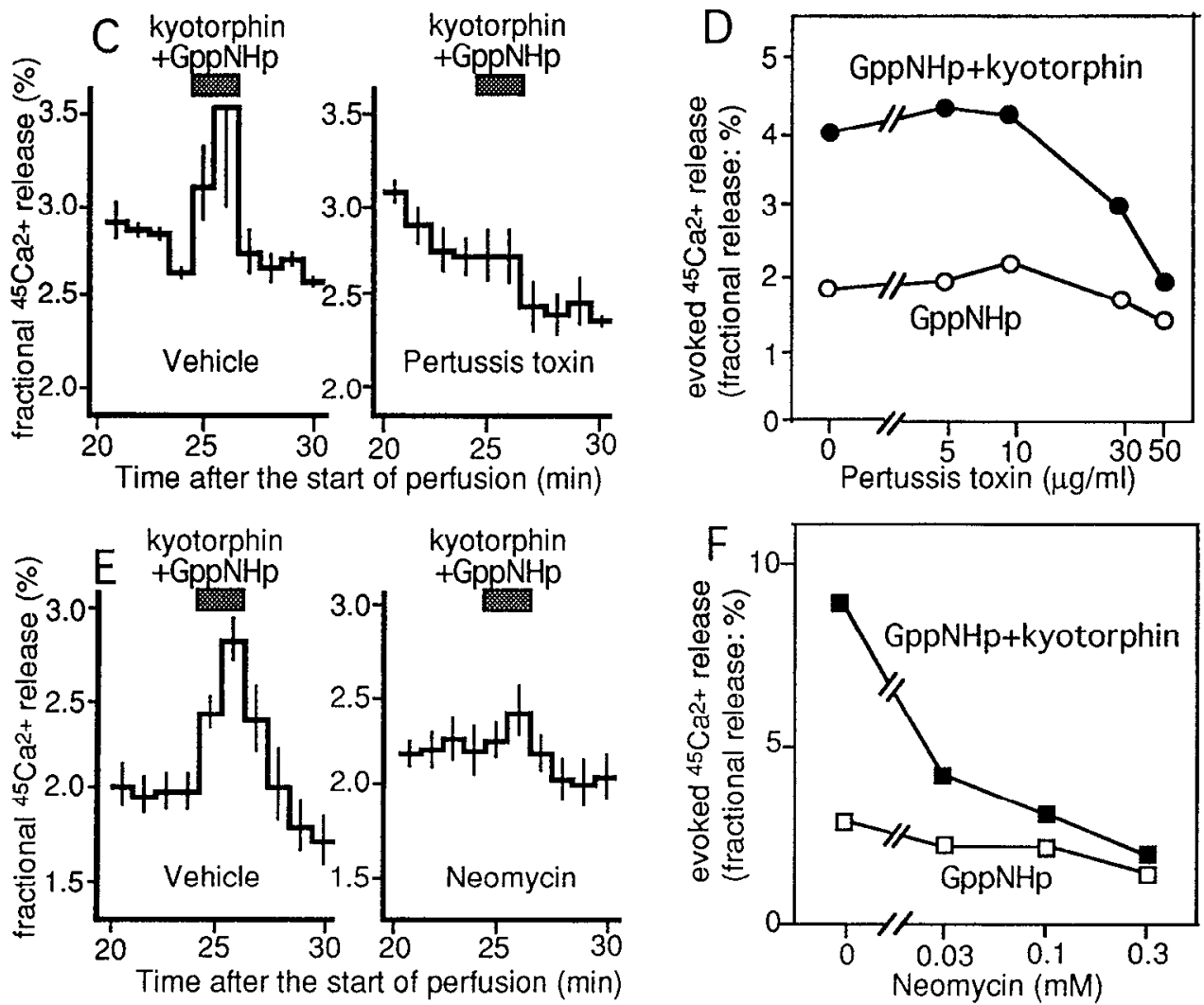

Figure 5. Kinetics of kyotorphin- and GppNHp-evoked ${ }^{45} \mathrm{Ca}^{2+}$ release from resealed SPM vesicles and involvements of PTX substrate G-proteins and PLC. $A$, Kyotorphin- and/or GppNHp-evoked ${ }^{45} \mathrm{Ca}^{2+}$ release were represented as with Ins $\mathrm{P}_{3}$-evoked increase $(\%)$ in the ${ }^{45} \mathrm{Ca}^{2+}$ release (see Results). $B$, Doublereciprocal plots of evoked ${ }^{45} \mathrm{Ca}^{2+}$ release by various combinations of kyotorphin and GppNHp. C, Efrects of PTX $(50 \mu \mathrm{g} / \mathrm{m}$ ) pretreatments of SPM on $100 \mu \mathrm{M}$ kyotorphin (plus $10 \mu \mathrm{M}$ GppNHp)-evoked ${ }^{45} \mathrm{Ca}^{2+}$ release. $D$, Blockade of kyotorphin (plus $10 \mu \mathrm{M}$ GppNHp)-evoked ${ }^{45} \mathrm{Ca}^{2+}$ release by pretreatments of SPM with various concentrations of PTX. E, Effects of neomycin $(0.3 \mathrm{mM})$ on $100 \mu \mathrm{M}$ kyotorphin (plus $10 \mu . \mathrm{M}$ (TppNHp)-evoked ${ }^{45} \mathrm{Ca}^{2+}$ release. $F$, Concentration-dependent inhibition of $100 \mu \mathrm{M}$ kyotorphin (plus $10 \mu \mathrm{M}$ GppNHp)-evoked ${ }^{45} \mathrm{Ca}^{2+}$ release by neomycin. blocked by PTX pretreatments. However, there was no marked reduction in the GppNHp-evoked release by PTX pretreatments. This finding might be explained by the data that PTX treatments block the functional coupling to receptors, but do not affect the intrinsic G-protein activity (Ueda et al., 1990). When PTXpretreated SPM was reconstituted with purified $G_{i 1}$, diluted in TMC, incubated with ${ }^{45} \mathrm{Ca}^{2+}$, and used for perfusion experiments, there was a complete recovery of kyotorphin-evoked ${ }^{45} \mathrm{Ca}^{2+}$ release (Fig. $6 C$ ). However, there was no significant recovery by reconstitution with purified $\mathrm{G}_{\mathrm{o}}$ (Fig. $6 D$ ). All these findings are consistent with our previous report that kyotorphin receptor is coupled to $G_{i 1}$ in rat brain membranes (Ueda et al., 1989).
Relationship between kyotorphin-evoked ${ }^{45} \mathrm{Ca}^{2+}$ release from resealed SPM vesicles and kyotorphinevoked ${ }^{45} \mathrm{Ca}^{2+}$ influx into unlysed synaptosomes in various regions of the brain

The kyotorphin-evoked ${ }^{45} \mathrm{Ca}^{2+}$ release from resealed SPM vesicles was high in the hippocampus and pons plus medulla, but low in the cerebellum. On the other hand, kyotorphin-evoked influx of ${ }^{45} \mathrm{Ca}^{2+}$ into unlysed synaptosomes from various brain regions was also high in the hippocampus and pons plus medulla, but low in the cerebellum. Accordingly, there was a significant positive correlationship between regional distributions of ${ }^{45} \mathrm{Ca}^{2+}$ release and ${ }^{45} \mathrm{Ca}^{2+}$ uptake ( $r=0.92$; Fig. 7). 


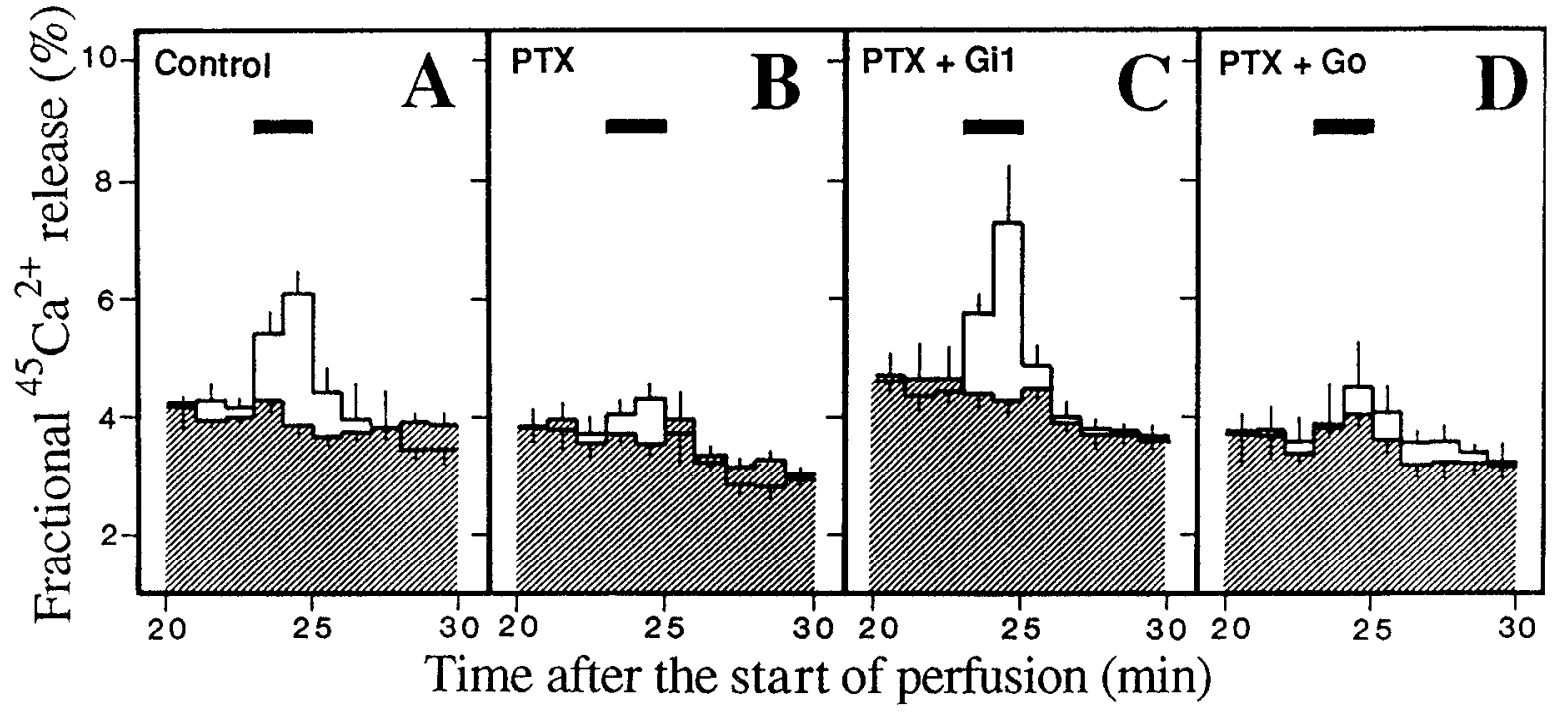

Figure 6. Recovery of kyotorphin-evoked ${ }^{45} \mathrm{Ca}^{2+}$ release from PTX-pretreated and resealed SPM vesicles by reconstitution with $\mathrm{G}_{\mathrm{i} /}$. SPM was treated without $(A)$ or with $50 \mu \mathrm{g} / \mathrm{ml}$ PTX $(B, C, D)$. PTX-treated synaptosomes were reconstituted without $(B)$ or with $20 \mathrm{pmol} /$ assay $\mathrm{G}_{\mathrm{i} 1}(C)$ or $\mathrm{G}_{\mathrm{o}}(D)$. Test drugs were added to the medium at the time indicated by the bar. Open or shaded column represents the data in separate experiments with $10 \mu \mathrm{M}$ GppNHp alone or with $10 \mu \mathrm{M}$ GppNHp plus $100 \mu \mathrm{M}$ kyotorphin, respectively. Results represent the mean \pm SEM from three separate experiments. Other details are given in the legend of Figure 2.

\section{DISCUSSION}

In addition to the accepted view that InsP $_{3}$ Inobilizes $\mathrm{Ca}^{2+}$ from microsomal organelles, such as rough (Henne et al., 1987) and smooth endoplasmic reticulum (Payne and Fein, 1987) and calciosome (Volpe et al., 1988), in various secretory cells (including neurons), there is growing evidence that $\mathrm{Ins}_{3}$ may have direct effects on calcium channels within the plasma membrane (for review, see Berridge, 1993; Fasolato et al., 1994; Clapham, 1995). A family of

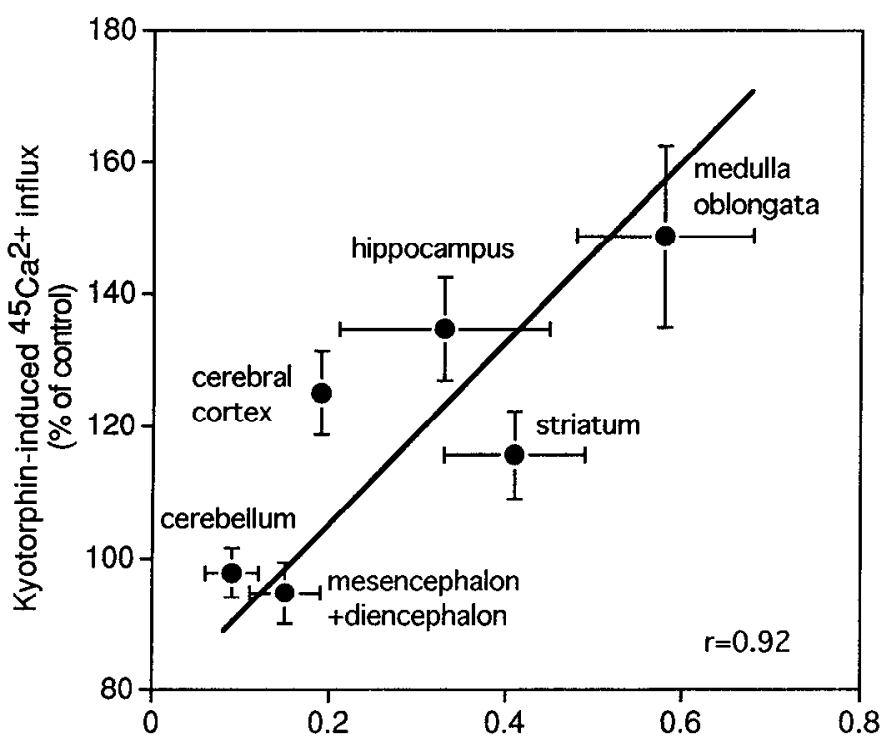

Kyotorphin-induced ${ }^{45} \mathrm{Ca}^{2}+$ release (\%)

Figure 7. Correlationship between regional distributions of kyotorphininduced ${ }^{45} \mathrm{Ca}^{2+}$ release from resealed SPM vesicles and kyotorphin-induced ${ }^{45} \mathrm{Ca}^{2+}$ influx into unlysed in the rat brain. Kyotorphin-induced ${ }^{45} \mathrm{Ca}^{2+}$ release from resealed SPM vesicles was measured as in the legend of Figure $5 A$. Kyotorphin-induced ${ }^{45} \mathrm{Ca}^{2+}$ influx into unlysed synaptosomes was measured in Experimental Procedures. In both experiments of ${ }^{45} \mathrm{Ca}^{2+}$ influx and release, $0.25 \mathrm{mg}$ of protein was used for each assay. Each point of data represents the mean \pm SEM from three to six separate experiments.
Ins $\mathrm{P}_{3}$ receptors has been identified with molecular diversity arising from both alternative splicing and separate genes (Furuichi et al., 1989; Sudhof et al., 1991; Ross et al., 1992). The immunoelectron microscopic analysis also revealed that $\mathrm{Ins}_{3}$ receptors are also found in the plasma membrane as well as in endoplasmic reticulum (ER) (Cunningham et al., 1993; Sharp et al., 1992). However, it remains unclear whether these $\operatorname{InsP}_{3}$ receptors found in different subcellular compartments are identical to one another. Most recently, findings suggest that different species of $\mathrm{InsP}_{3}$ receptors are involved in such different actions through plasma membranes or ER membranes. For example, the Ins $P_{3}$-induced entry of calcium in lymphocytes may be mediated by a new $\mathrm{InsP}_{3}$ receptor, which contains sialic acid and is localized in the plasma membrane (Khan et al., 1992). On the other hand, the binding protein at the plasma membrane of olfactory cells was equally sensitive to $\operatorname{InsP}_{3}$ and $\mathrm{InsP}_{4}$. By contrast, the InsP $\mathrm{P}_{4}$ sensitive calcium channel in the plasma membrane of endothelial cells was insensitive to InsP $P_{3}$. Thus, it may be true that multiple forms of InsP $\mathrm{P}_{3}$ receptor exist in various cells and that some species of such receptors are involved in calcium transport through the plasma membrane.

Here we demonstrated the $\mathrm{InsP}_{3}$-evoked $\mathrm{Ca}^{2+}$ transport system in the plasma membrane of nerve terminals in the brain using unique experiments with resealed vesicles. Such preparations likely have both inside-out and outside-out types of vesicles, as shown in Figure $8, A$ and $B$. In the present experiments, the ATP-dependent incorporation of ${ }^{45} \mathrm{Ca}^{2+}$ was potentiated by calmodulin (Fig. $1 C$ ). Because there is a report that $\mathrm{Ca}^{2+}$-dependent ATPase $\left(\mathrm{Ca}^{2+}\right.$ pump) in plasma membranes is activated by calmodulin (Verma et al., 1989), the present finding may provide important evidence, suggesting that the resealed SPM preparations have inside-out type of vesicles. However, we have no other evidence for the existence of inside-out vesicles independent of the biochemical assays. To our knowledge, the best evidence might be obtained from the immunoelectron microscopical study using specific antibodies against membrane-associated proteins (or their peptide motives), which are intra- and extracellularly located. This should be the subject of future experiments. 


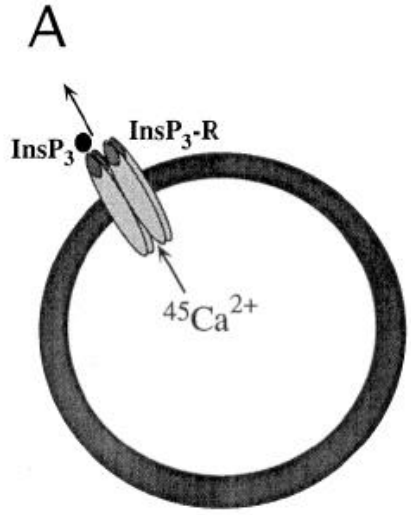

Inside-out
B

C

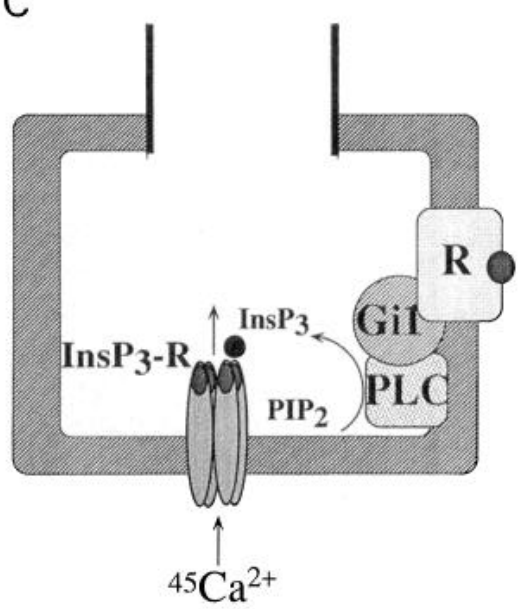

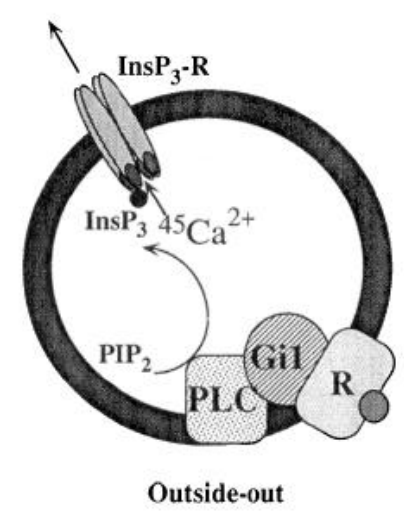

Figure 8. Proposed model of inside-out and outside-out types of resealed vesicles and working hypothesis of presynaptic InsP $_{3}$ receptor channel in plasma membranes of nerve terminals. A, Inside-out type of resealed SPM vesicles. $B$, Outside-out type of resealed SPM vesicles. $C$, In this model, there is a major calcium channel, a voltage-operated calcium channel (VOC), and a relatively minor calcium channel, InsP $_{3}$ receptor, in nerve terminals involved in the $\mathrm{Ca}^{2+}$ influx. When agonist (kyotorphin) binds to the presynaptic receptor, $\mathrm{G}_{i 1}$ and PLC are activated. Produced InsP $\mathrm{P}_{3}$ activates the InsP $\mathrm{P}_{3}$ receptor located in plasma membranes of nerve terminals, followed by gating of the calcium channel. Organelles in nerve terminals may not play important roles in the $\mathrm{InsP}_{3}$-evoked $\mathrm{Ca}^{2+}$ mobilization.

As shown in Figure $1 D$, the ATP-dependent incorporation of ${ }^{45} \mathrm{Ca}^{2+}$ in resealed SPM vesicles was much more efficiently inhibited by saponin than such an ATP-dependent incorporation into unlysed microsomes. Because saponin is well known to form micelles with cholesterol highly located in plasma membranes but not in ER (Inamitsu and Ohtsuki, 1984), it is evident that such an ATP-dependent ${ }^{45} \mathrm{Ca}^{2+}$ incorporation into SPM preparations is mostly attributed to that into inside-out vesicles made of plasma membranes.

One of the major findings in this report is that $\mathrm{InsP}_{3}$ plays a role in $\mathrm{Ca}^{2+}$ transport through such plasma membranes. Because such effects in preparations of resealed SPM vesicles were relatively specific for InsP $\mathrm{P}_{3}$, and the $\mathrm{InsP}_{3}$-evoked ${ }^{45} \mathrm{Ca}^{2+}$ release was saturable in kinetic analysis, it is evident that the $\mathrm{InsP}_{3}$ receptor is involved in such mechanisms. The ${ }^{45} \mathrm{Ca}^{2+}$ release by $\mathrm{InsP}_{4}$ was partial in potency, whereas it shows a saturability in kinetic analysis. From the finding that the $K_{\mathrm{m}}$ value for InsP $\mathrm{P}_{4}$ is similar to that of $\mathrm{InsP}_{3}$, and the maximal response by $\mathrm{InsP}_{4}$ is lower than that by $\mathrm{InsP}_{3}$, it is very likely that different $\mathrm{InsP}_{3}$ and $\mathrm{InsP}_{4}$ sites exist. This view is consistent with the report using olfactory cells (Kalinoski et al., 1992), although further characterizations of $\mathrm{InsP}_{4}$-evoked ${ }^{45} \mathrm{Ca}^{2+}$ transport remain to be done. In Figure $3 A$, we showed weak effects by Ins, InsP, and InsP $\mathrm{P}_{2}$ compared with those by $\mathrm{InsP}_{3}$ and $\mathrm{InsP}_{4}$. Because the concentration-response curves of InsP and $\mathrm{InsP}_{2}$ were bell-shaped, kinetic analyses of these actions could not be performed. On the other hand, Ins evoked a weak but concentration-dependent ${ }^{45} \mathrm{Ca}^{2+}$ release. The maximal response was $25 \%$ of $\mathrm{InsP}_{3}$ action. But it remains unclear whether this effect is attributed to the action on $\operatorname{InsP}_{3}, \operatorname{InsP}_{4}$, or other receptors. Further studies must be done to fully characterize these weak responses.

Throughout various subcellular fractions, the $\mathrm{InsP}_{3}$-evoked ${ }^{45} \mathrm{Ca}^{2+}$ release was most potent in resealed preparations using SPM. Although fractions of microsomes and myelins are expected to contain plasma membranes of neurons and glia, the $\mathrm{InsP}_{3}$ actions in such preparations were much lower than that in the synaptosomal fraction (Table 1), which is expected to contain presynaptic nerve terminals and nerve ending particles (Whittaker et al., 1964). It is evident that SPM, but not other organelles in nerve terminals (including ER), is responsible for such $\mathrm{InsP}_{3}$ actions because the $\operatorname{InsP}_{3}$-action was most potent in SPM preparations among synaptosomal subfractions (Table 1), and there was no significant Ins $\mathrm{P}_{3}$-evoked ${ }^{45} \mathrm{Ca}^{2+}$ release in saponinpermeabilized synaptosomes where ${ }^{45} \mathrm{Ca}^{2+}$ had been previously taken up into intrasynaptosomal organelles through calcium pump (Fig. $4 C, D$ ). The finding that the $\mathrm{InsP}_{3}$-evoked ${ }^{45} \mathrm{Ca}^{2+}$ release in SPM preparations was abolished by saponin treatment (Fig. $2 G$ ) also supports the view that presynaptic plasma membranes are responsible for $\mathrm{InsP}_{3}$ actions. Most recently, several mechanisms via $\mathrm{InsP}_{3}$ actions are reported to be involved in the calcium transport through plasma membranes (Fasolato et al., 1994). They are divided into two mechanisms via second messenger-operated channels (SMOC) and calcium releaseactivated channels (CRAC). The former mechanism is related to calcium channels directly gated by $\mathrm{InsP}_{3}$ and to those gated by Ins $P_{3}$ plus $\mathrm{Ca}^{2+}$, which is mobilized from ER by InsP $\mathrm{P}_{3}$. The latter mechanism, on the other hand, includes the involvement of $\mathrm{Ca}^{2+}$ influx factor (CIF). However, it is unlikely that both SMOC coupled to $\mathrm{Ca}^{2+}$ mobilization from ER and CIF-regulated CRAC are involved in the present experiments, because resealed SPM vesicles are made of subfractionated membranes, where ER and CIF are expected to be absent. Thus, it is strongly suggested that InsP $\mathrm{P}_{3}$ mediates $\mathrm{Ca}^{2+}$ transport via SPM in nerve terminals.

Another major finding is that such $\mathrm{InsP}_{3}$-mediated $\mathrm{Ca}^{2+}$ transport mechanisms through presynaptic plasma membranes are linked to the presynaptic receptor, which is coupled to PLC via an activation of $G_{i 1}$. The present strategy using resealed vesicles has advantages in that the membrane is able to be treated with PTX and reconstituted with purified $\mathrm{G}$-proteins before ${ }^{45} \mathrm{Ca}^{2+}$ uptake and that outside-out-type vesicles possibly exist as well as insideout ones. Previously, we have reported that kyotorphin (tyrosinearginine) releases methionine-enkephalin from brain slices (Takagi et al., 1979) by possible mechanisms through an increase in $\left[\mathrm{Ca}^{2+}\right]_{\mathrm{i}}$ in brain slices or through $\mathrm{a}^{45} \mathrm{Ca}^{2+}$ influx into synaptosomes (Ueda et al., 1986). After this report, we have demonstrated that kyotorphin releases ${ }^{45} \mathrm{Ca}^{2+}$ from such resealed vesicles of lysed synaptosomes as presented here (Ueda et al., 1987). Recently, it was revealed that kyotorphin receptor is coupled to PLC through an activation of $\mathrm{G}_{\mathrm{i} 1}$ in reconstitution experiments (Ueda et al., 1989). From such findings, we decided to clarify the possible involvement of $\mathrm{InsP}_{3}$ in kyotorphin receptor-mediated ${ }^{45} \mathrm{Ca}^{2+}$ transport through SPM by reconstitution experiments. 
The kyotorphin-evoked ${ }^{45} \mathrm{Ca}^{2+}$ release was abolished in the presence of neomycin, an inhibitor of PLC (Fig. 5E,F). The evidence for the $\mathrm{G}$-protein involvement in kyotorphin actions was demonstrated here, as follows. (1) Kyotorphin potentiated the ${ }^{45} \mathrm{Ca}^{2+}$ release evoked by GppNHp, an unhydrolyzable analog of GTP (Fig. $5 A, B$ ). The change was observed in the decrease of $K_{\mathrm{m}}$ value for GppNHp, which is consistent with the functional coupling between many receptors and G-proteins (Gilman, 1987). (2) The kyotorphin-evoked ${ }^{45} \mathrm{Ca}^{2+}$ release was abolished by PTX treatment of SPM membranes (Fig. 5C,D). (3) Such kyotorphin actions were recovered by reconstitution of PTX-treated SPM with purified $G_{i 1}$, but not with $G_{o}$ (Fig. 6), in good accord with our previous reconstitution experiments measuring GTPase and PLC activities (Ueda et al., 1989). Here we also measured ${ }^{45} \mathrm{Ca}^{2+}$ influx into unlysed synaptosomes and ${ }^{45} \mathrm{Ca}^{2+}$ release from resealed $\mathrm{SPM}$ vesicles. As shown in Figure 7, the distribution of kyotorphincrokcd ${ }^{45} \mathrm{Ca}^{2+}$ relcase from resealed SPM vesicles was closely related to those of kyotorphin-mediated ${ }^{45} \mathrm{Ca}^{2+}$ influx. Thus, it is evident that kyotorphin receptors mediate an activation of PLC through $G_{i 1}$ in such reconstitution experiments, followed by an opening of Ins $_{3}$-gated calcium channels located in the plasma membrane of nerve terminals.

There are many reports suggesting that $\mathrm{InsP}_{3}$-sensitive calcium stores are present in ER and related to the hormone release in endocrine cells. In the CNS, the nerve terminal is a functional component related to neurotransmitter release. The concentration of $\mathrm{Ca}^{2+}$ in nerve terminals is closely related to the regulation of neurotransmitter release, and, hence, the receptor mechanism mediating calcium mobilization by $\operatorname{InsP}_{3}$ in nerve terminals might play an important role in the presynaptic regulation (Fig. $8 \mathrm{C}$ ).

The present study provides evidence that the receptor operation of calcium ion channel activity is mediated by $\operatorname{InsP}_{3}$ through an activation of G-protein and PLC in neuronal systems, particularly in preparations closely related to presynaptic nerve terminals.

\section{REFERENCES}

Berridge MJ (1993) Inositol trisphosphate and calcium signalling. Nature 361:315-325.

Berridge MJ, Irvine RF (1984) Inositol phosphates and cell signalling. Nature 312:315-321.

Clapham DE (1995) Replenishing the stores. Nature 375:634-635.

Cockcroft S, Gomperts BD (1985) Role of guanine nucleotide binding protein in the activation of polyphosphoinositide phosphodiesterase. Nature 314:534-536.

Cinningham AM, Ryugo DK, Sharp AH, Reed RR, Snyder SH, Ronnett GV (1993) Neuronal inositol 1,4,5-trisphosphate receptor localized to the plasma membrane of olfactory cilia. Neuroscience 57:339-352.

Ehrlich BE, Watras J (1988) Inositol 1,4,5 trisphosphate activates a channel from smooth muscle sarcoplasmic reticulum. Nature 336:583-586.

Fabiato A, Fabiato F (1979) Calculator programs for computing the composition of the solutions containing multiple metals and ligands used for experiments in skinned muscle cells. J Physiol (Paris) 75:463-505.

Fasolato C, Innocenti B, Pozzan T (1994) Receptor-activated $\mathrm{Ca}^{2+}$ influx: how many mechanisms for how many channels. Trends Pharmacol 15:77-83.

Furuichi T, Yoshikawa S, Miyawaki A, Wada K, Maeda N, Mikoshiba K (1989) Primary structure and functional expression of the inositol 1,4,5trisphosphate-binding protein $\mathbf{P} 400$. Nature 342:32-38.

Gerfen CR, Choi WC, Suh PG, Rhee SG (1988) Phospholipase C I and II brain isozymes: immunohistochemical localization in neuronal systems in rat brain. Proc Natl Acad Sci USA 85:3208-3212.

Gilman AG (1987) G protcin: transduccrs of receptor-gencrated signals. Annu Rev Biochem 56:615-649.

Guillemette G, Balla T, Baukal AJ, Catt KJ (1988) Characterization of inositol 1,4,5-trisphosphate receptors and calcium mobilization in a hepatic plasma membrane fraction. J Biol Chem 263:4541-4548.
Henne V, Pïper A, Soling H-D (1987) Inositol 1,4,5-trisphosphate and 5 -GTP induced calcium release from different intracellular pools. FEBS Lett 218:153-158.

Inamitsu T, Ohtsuki I (1984) Charactcrization of ATP-dependent $\mathrm{Ca}^{2+}$ uptake by canine brain microsomes with saponin. Eur J Biochem 145:115-121.

Kalinoski DL, Aldinger SB, Boyle AG, Huque T, Marecek JF, Prostwich GD, Restrepo D (1992) Characterization of a novel inositol 1,4,5 trisphosphate receptor in isolated olfactory cilia. Biochem J 281:449-456.

Kasper CB (1971) Biochemical distinctions between the nuclear and microsomal membranes from rat hepatocytes. J Biol Chem 246:577-581.

Katada T, Oinuma M, Kusakabe K, Ui M (1987) A new GTP-binding protein in brain tissues serving as the specific substrate of islet-activating protein, pertussis toxin. FEBS Lett 213:353-358.

Khan AA, Steiner JP, Snyder SH (1992) Plasma membrane inositol 1,4,5trisphosphate receptor of lymphocytes: selective enrichment in sialic acid and unique binding specificity. Proc Natl Acad Sci USA 89:2849-2853

Kobayashi S, Somlyo AV, Somlyo AP (1988) Heparin inhibits the inositol 1,4,5-trisphosphate-dependent, but not the independent calcium release induced by guanine nucleotide in vascular smooth muscle. Biochem Biophys Res Commun 153:625-631.

Kuno M, Gardner P (1987) Ion channels activated by inositol 1,4,5trisphosphate in plasma membrane of human T-lymphocytes. Nature 326:301-304.

Misawa H, Ueda H, Katada T, Ui M, Satoh M (1995) A subtype of opioid k-receptor is coupled to inhibition of Gil-mediated phospholipase C activity in the guinea pig cerebellum. FEBS Lett 361:106-110.

Payne R, Fein A (1987) Inositol 1,4,5 trisphosphate releases calcium from specialized sites within Limulus photoreceptors. J Cell Biol 104:933-937.

Penner R, Matthews G, Neher E (1988) Regulation of calcium influx by second messengers in rat mast cells. Nature 334:499-504.

Ross CA, Danoff SK, Schell MJ, Snyder SH, Ullrich A (1992) Three additional inositol 1,4,5-trisphosphate receptors: molecular cloning and differential localization in brain and peripheral tissues. Proc Natl Acad Sci USA 89:4265-4269.

Sharp AH, Snyder SH, Nigam SK (1992) Inositol 1,4,5-trisphosphate receptors, localization in epithelial tissue. J Biol Chem 267:7444-7449.

Sudhof TC, Newton CL, Archer BT, Ushkaryov YA, Mignery GA (1991) Structure of a novel InsP ${ }_{3}$ receptor. EMBO J 10:3199-3206.

Takagi H, Shiomi H, Ueda H, Amano H (1979) A novel analgesic dipeptide from bovine brain is a possible met enkephalin releaser. Nature 282:410-412.

Ueda H, Yoshihara Y, Takagi H (1986) A putative met-enkephalin releaser, kyotorphim enhances intracellular $\mathrm{Ca}^{2+}$ in the synaplosomes. Biochem Biophys Res Comm 137:897-902.

Ueda H, Fukushima N, Yoshihara Y, Takagi H (1987) A met-enkephalin releaser, kyotorphin-induced release of plasma membrane-bound $\mathrm{Ca}^{2+}$ from rat brain synaptosomes. Brain Res 419:197-200.

Ueda H, Yoshihara Y, Misawa H, Fukushima N, Katada T, Ui M, Takagi H, Satoh M (1989) The kyotorphin (tyrosine-arginine) receptor and a selective reconstitution with purified Gi, measured with GTPase and phospholipase C. assays. J Riol Chem 264:3732-3741.

Ueda H, Uno S, Harada J, Kobayashi I, Katada T, Ui M, Satoh M (1990) Evidence for receptor-mediated inhibition of intrinsic activity of GTPbinding protein, Gil and $\mathrm{Gi} 2$, but not Go reconstitution experiments. FEBS Lett 266:178-182.

Verity MA (1972) Cation modulation of synaptosomal respiration. J Neurochem 19:1305-1317

Verma AK, Filoteo AG, Stanford DR, Wieben ED, Penniston JT, Strehler EE, Fischer R, Heim R, Vogel G, Mathews S, Strehler-Page M-A, James P, Vorherr T, Krebs J, Carafoli E (1989) Complete primary structure of a human plasma membrane $\mathrm{Ca}^{2+}$ pump. J Biol Chem 263:14152-14159.

Volpe P, Krause K-H, Hashimoto S, Zorzato F, Pozzan T, Meldolesi J, Lew DP (1988) "Calciosome," a cytoplasmic organelle: the inositol 1,4,5-trisphosphate-sensitive $\mathrm{Ca}^{2+}$ store of nonmuscle cells? Proc Natl Acad Sci USA 85:1091-1095.

Whittaker VP, Michaelson IA, Kirkland RJ (1964) The separation of synaptic vesicles from nerve-ending particles (synaptosomes). Biochem J 90:293-303.

Worley PF, Baraban JM, Supattapone S, Wilson VS, Snyder SH (1987) Characterization of inositol 1,4,5-trisphosphate receptors and calcium mobilization in a hepatic plasma membrane fraction. $\mathbf{J}$ Biol Chem 263:4541-4548. 